\title{
Synthesis and biological evaluation of novel 1,5-benzothiazepin-4(5H)-ones as potent antiangiogenic and antioxidant agents
}

\author{
Channegowda V. Deepu ${ }^{a}$, Goravanahalli M. Raghavendrab ${ }^{b}$, Nanjappagowda D. Rekha ${ }^{c}, K$. \\ Mantelingu $^{\mathrm{b}}$, Kanchugarakoppal S. Rangappa ${ }^{\mathrm{b}}$ and Doddamedur G. Bhadregowda ${ }^{\mathrm{a}^{*}}$
}

${ }^{a}$ Department of Studies in Chemistry, Yuvaraja's College, University of Mysore, Mysore-570005, India

${ }^{b}$ Department of Studies in Chemistry, Manasagangothri, University of Mysore, Mysore-570006, India

${ }^{c}$ Department of Studies in Biotechnology, JSS College of Arts, Commerce and Science, Ooty road, Mysore-570002, India \begin{abstract}
A B S T R A C T
Novel 1,5-benzothiazepin-4-(5H)-one derivatives (8a-8g) have been synthesized by intramolecular cyclization of 6 using propyl phosphonic anhydride $\left(\mathbf{T}_{3} \mathbf{P}\right)$ as a cyclodehydrating agent. The anti-angiogenic and anti-oxidant properties of the new derivatives were then evaluated. Compounds $\mathbf{8 b}, \mathbf{8 d}, \mathbf{8 e}, \mathbf{8 f}$ and $\mathbf{8 g}$ exhibited very good inhibition of capillary proliferation, thus proving their anti-angiogenic properties. In addition, the in vitro antioxidant activities of these compounds were evaluated using diphenyl picryl hydrazine (DPPH), $\mathrm{OH}^{-}$, metal ion-chelating and $\mathrm{NO}$ (nitric oxide) assays, and the results compared with butylated hydroxytoluene (BHT), a well known anti-oxidant. Compounds 8a-8g showed excellent free-radical scavenging activities in the metal ion-chelating assay, and compounds 8f and 8g showed nitric oxide radical scavenging properties at a concentration of 20-100 $\mu \mathrm{g} / \mathrm{mL}$, and are thus more potent than BHT.
\end{abstract}

\section{Introduction}

Angiogenesis is the development of new blood vessels from pre-existing vasculatures and this has been well recognized as an essential hallmark for the growth, invasion and metastasis of tumors. ${ }^{1}$ Deregulation of angiogenesis under pathological conditions causes several diseases like diabetic retinopathy, rheumatoid arthritis, and cancer. ${ }^{2}$ Thus, the inhibition of tumor angiogenesis provides a therapeutic strategy for treating different types of cancers. In many cases anti-angiogenic agents act as cytostatics and prevent the growth of tumors, though it is thought that they can be made more successful in cancer chemotherapy by combining with cytotoxic agents. ${ }^{3}$

Antioxidants are molecules inhibiting the oxidation of other molecules thereby preventing the cell death that occurs due to the release of free radicals. ${ }^{4}$ Reactive oxygen species generated in the cell during anti-oxidation initiate and promote tumor growth as well as other degenerative diseases such as * Corresponding author. Te1: +91 821 6558562; +91 821 2412191/2419661; fax:+91 821 2412191; +91 8212419239

E-mail address: dgbycm@gmail.com (D.G. Bhadregowda) 
heart attacks, strokes, arthritis and cataracts. ${ }^{5}$ Minimizing oxidative damage may be an important approach to the primary treatment of these diseases, since antioxidants prevents the free radical formation, or interrupt an oxidizing chain reaction. Thus, antioxidants can be regarded as important factors for the treatment of cancer. Compounds functioning with groups endowed with potential antioxidant properties are considered as new drugs for chemoprevention and chemotherapy. ${ }^{6}$ Therefore, the development of synthetic compounds, capable of scavenging free radicals, has been a great interest.

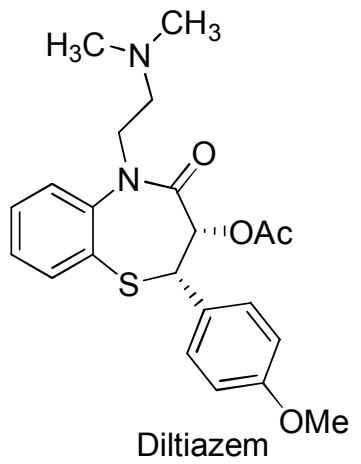

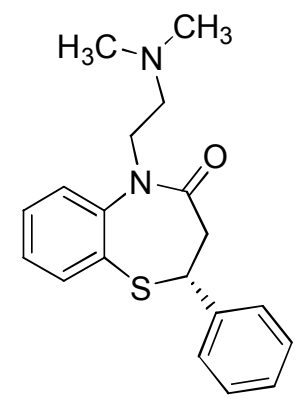

Thiazesim<smiles>OCCOCCN1CCN(C2=Nc3ccccc3Sc3ccccc32)CC1</smiles>

Quetiapine

Fig. 1. Examples of 1,5-benzothiazepine drugs

1,5-Benzothiazepines constitute an important class of privileged scaffolds as a result of their immense chemotherapeutic applications, such as calcium channel blockers, ${ }^{7}$ angiotensin converting enzyme inhibitors, ${ }^{8}$ anticonvulsant, ${ }^{9}$ anti-HIV, ${ }^{10}$ anti-hypertensive, ${ }^{11}$ platelet aggregation inhibitors ${ }^{12}$ and cytotoxic ${ }^{13}$ agents. They have also been reported as potent antibacterial, ${ }^{14}$ antimicrobial, ${ }^{15}$ and Bradykinin agonists. ${ }^{16}$ Diltiazem [Fig. 1], ${ }^{17}$ a well-known angina-relieving calcium channel blocker and coronary vasodilator, and Thiazesim, ${ }^{18}$ used as an antidepressant, and the antipsychotic Quetiapine, ${ }^{19}$ possess 1,5-benzothiazepine skeletons.

Because of their interesting biological properties, functionalized 1,5-benzothiazepin-4(5H)ones represent an important class of heterocyclic compounds. The major approaches, for synthesis of 1,5benzothiazepinones are cyclization and ring expansion. The most widely employed methods involves, nucleophilic attack of substituted 2-aminothiophenols or 2-nitrothiophenols on aliphatic electrophiles ${ }^{20}$ and the reaction of 2 -fluoronitroarenes with $\beta$-mercapto acid, followed by nitro group reduction and cyclisation. $^{21}$ (Scheme 1).<smiles>Nc1ccccc1S</smiles><smiles>CCOC(=O)C(=Cc1ccccc1)C(=O)OCC</smiles><smiles>O=C1Nc2ccccc2SC(c2ccccc2)C1CO</smiles><smiles>C[C@H]1CC(=O)Nc2ccccc2S1</smiles><smiles>NCCC(CS)C(=O)O</smiles><smiles>C#CC#C</smiles><smiles>N[C@H]1CSc2ccccc2NC1=O</smiles>

Scheme 1. Synthetic methods for preparation of 1,5-benzothiazepin-4(5H)-ones 
In continuation of our work on development of synthetic methodologies for bioactive molecules, ${ }^{22,23}$ we report herein an efficient, versatile and convenient synthetic route which provides rapid access to 1,5-benzothiazepin- $4(5 \mathrm{H})$-ones using a multistep strategy from readily available diethyl di- $n$-butyl malonate 1 and a new coupling agent T3P (Figure 2) and their anti-angiogenic and anti-oxidant properties.

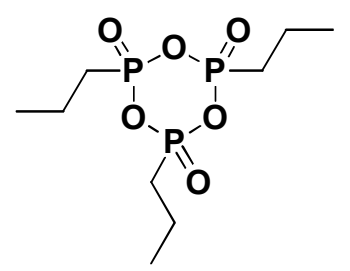

\section{Results and discussion}

Fig. 2. Structure of T3P

\subsection{Chemistry}

The synthesis of 1,5-benzothiazepin-4(5H)-one derivatives was accomplished in seven steps as outlined in Scheme 2.<smiles>CCCCC(CCCC)(C(=O)OCC)C(=O)OCC</smiles>

1<smiles>CCCCC(CO)(CCCC)C(=O)OCC</smiles>

2<smiles>CCCCC(CO)(CBr)C(=O)O</smiles>

3

4<smiles>CCCCC(CCCC)(CCCC)CSc1cc(OC)ccc1N</smiles><smiles>CCCCC1(CCCC)CSc2cc(OC)ccc2NC1=O</smiles><smiles>CCCCC1(CCCC)CSc2cc(OC)ccc2N([R8]Br)C1=O</smiles>

$$
\begin{array}{rlr}
\mathrm{R} & =\mathrm{Me} & \mathbf{8 a} \\
& =\mathrm{C}_{2} \mathrm{H}_{5} & \mathbf{8 b} \\
& =\text { allyl } & \mathbf{8 c} \\
& =\text { n-butyl } & \mathbf{8 d} \\
& =\text { isobutyl } & \mathbf{8 e} \\
& =\text { 1-isopropyl urea } & \mathbf{8 f} \\
& =\text { 1-propylpiperidine } & \mathbf{8 g}
\end{array}
$$

(a) DIBAL-H, $\mathrm{NaBH}_{4}$; (b) $\mathrm{NaOH}, \mathrm{MeOH}$; (c) $\mathrm{HBr}$, conc. $\mathrm{H}_{2} \mathrm{SO}_{4}$; (d) aq. $\mathrm{KOH}, 4$, THF; (e) $\mathrm{T}_{3} \mathrm{P}$, $\mathrm{Et}_{3} \mathrm{~N}$; (f) DMF, NaH, RX.

Scheme 2. Synthetic route of 1,5-benzothiazepin-4(5H)-one derivatives 
First, ethyl-[2- $n$-butyl-2-hydroxymethyl]hexanoate 2 was obtained by selective reduction of diethyl di- $n$-butyl malonate 1 in toluene using DIBAL- $\mathrm{H}$ and $\mathrm{NaBH}_{4}$ under $\mathrm{N}_{2}$ atmosphere. Compound ethyl(2-n-butyl-2-hydroxymethyl)hexanoic acid 3 was then synthesized in good yield by hydrolysis of ethyl(2-n-butyl-2-hydroxymethyl)hexanoate 2 in methanol and $\mathrm{NaOH}$. 2-Bromomethyl-2- $n$-butylhexanoic acid 4 was then obtained by treating ethyl-(2-n-butyl-2-hydroxymethyl)hexanoic acid 3 with $48 \%$ (aq.) $\mathrm{HBr}$ and conc. $\mathrm{H}_{2} \mathrm{SO}_{4}$. Amino-6-methoxy benzothiazole 5 in $\mathrm{KOH}$ solution was condensed with 2bromomethyl-2- $n$-butylhexanoic acid 4 in THF under $\mathrm{N}_{2}$ atmosphere to yield the desired product, 2$\{[(2-a m i n o-5-m e t h o x y p h e n y l) t h i o] m e t h y l\}-2-n$-butylhexanoic acid 6. Finally, the intramolecular cyclization of $\mathbf{6}$ using $\mathbf{T}_{\mathbf{3}} \mathbf{P}$ as cyclodehydrating agent afforded the compound 3,3-di- $n$-butyl-8methoxy-2,3-dihydro-1,5-benzothiazepin-4(5H)-one 7. Compounds 8a-8g were obtained in good yields (85-92\%) by alkylation of 7 with different alkyl halides in DMF using $\mathrm{NaH}$ as a base under $\mathrm{N}_{2}$ atmosphere. We concluded, based on previously published work, that this is the first report in which $\mathrm{T}_{3} \mathrm{P}$ is used as a cyclodehydrating agent in the synthesis of the 1,5-benzothiazepin- $4(5 \mathrm{H})$-one core structure 7. The structures of all the synthesized compounds were confirmed by IR, ${ }^{1} \mathrm{H}$ NMR and mass spectra.

\subsection{Antioxidant activities}

\subsubsection{DPPH radical scavenging activity}

Antioxidants are characterized by their ability to scavenge free radicals. Proton-radical scavenging action is an important attribute of antioxidants, which is measured by DPPH scavenging assay. DPPH, a protonated radical has significant absorbance maxima at $517 \mathrm{~nm}$ which decreases in the presence of antioxidant due to the scavenging of the proton radical ${ }^{24}$. The hydrogen donating ability of the antioxidant molecule contributes to its free radical scavenging potential. The DPPH radical scavenging activity shown by compounds $\mathbf{8 a - 8 g}$ is due to their H-donating capacity. In the present investigation, compounds 8a-8g showed low DPPH radical-scavenging activities when compared to $\mathrm{BHT}$ (IC $\mathrm{I}_{50}$ values from $136.36 \mu \mathrm{g} / \mathrm{mL}$ to $661.03 \mu \mathrm{g} / \mathrm{mL}$, BHT has an $\mathrm{IC}_{50}$ value of $10.87 \mu \mathrm{g} / \mathrm{mL}$ ).

\section{Hydroxyl radical scavenging activity}

The hydroxyl radical is an extremely reactive free radical formed in biological systems and has been implicated as a highly damaging species in free radical pathology as it is capable of damaging biomolecules found in living cells. ${ }^{25}$ Hydroxyl radical has the capacity to cause breakage of DNA, which results in cytotoxicity, carcinogenesis and mutagenesis. In addition, this radical species is rapidly initiates lipid peroxidation, removing hydrogen atoms from unsaturated fatty-acids. ${ }^{25}$ In the present study, 8a-8g showed moderate hydroxyl radical scavenging activity (8f with $\mathrm{IC}_{50}$ value of $13.64 \mu \mathrm{g}$ and 8b showing $82.94 \mu \mathrm{g} / \mathrm{mL}$ ) when compared to standard BHT ( IC $_{50}$ value $10.83 \mu \mathrm{g} / \mathrm{mL}$ ). The hydrogen-donating capacity of compounds $\mathbf{8 a - 8 g}$ was observed to be moderate compared to BHT as shown in Table 1.

Table 1. Free radical scavenging activity of the compounds $8 \mathrm{a}-8 \mathrm{~g}$

\begin{tabular}{lcccc}
\hline $\begin{array}{l}\text { Antioxidant activities } \\
\text { Compounds }\end{array}$ & \multicolumn{5}{c}{ IC 50 values $(\mu \mathrm{g} / \mathrm{mL})$} & \\
\hline & $\mathrm{NO}$ & $\mathrm{Fe}^{2+}$ & $\mathrm{OH}$ & $\mathrm{DPPH}$ \\
\hline $8 \mathrm{a}$ & 85.5 & 97.91 & 33.56 & 136.36 \\
$8 \mathrm{~b}$ & 56.40 & 81.20 & 82.94 & 321.43 \\
8c & 56.63 & 105.60 & 36.47 & 473.10 \\
8d & 58.46 & 39.59 & 38.61 & 661.03 \\
8e & 67.42 & 58.25 & 30.06 & 399.61 \\
$8 \mathrm{f}$ & 35.01 & 104.69 & 13.64 & 429.62 \\
$8 \mathrm{~g}$ & 16.55 & 96.38 & 37.64 & 301.94 \\
BHT & 51.79 & 213.45 & 10.83 & 10.87 \\
\hline
\end{tabular}




\subsubsection{Nitric oxide radical scavenging activity}

Under physiological conditions, nitric oxide (NO) plays important roles as a neurotransmitter, vasodilator and in the immunological system it fights against tumor cells and infectious agents. During inflammatory reactions, NO is produced by the inducible enzyme NO synthase (iNOS) in cells like macrophages, hepatocytes, and renal cells after stimulation by lipopolysaccharide (LPS), tumor necrosis factor (TNF- $\alpha$ ), interleukin (IL-1) or interferon (INF- $\gamma$ ), and acts as a defense and regulatory signal molecule. However, NO is pathogenic when present in excess, as it is a reactive radical itself, and directly damages normal tissues. ${ }^{26}$ Further, NO can also react with superoxide anion radical to form the even stronger oxidant, peroxynitrite. ${ }^{27}$ Among the samples studied, 8g and $\mathbf{8 f}$ showed highly significant $(\mathrm{P}<0.01)$ activity in scavenging $\mathrm{NO}$ radical with $\mathrm{IC}_{50}$ values of 16.55 and $35.01 \mu \mathrm{g} / \mathrm{mL}$, respectively, when compared to $51.79 \mu \mathrm{g} / \mathrm{mL}$ recorded for BHT (Table 1).

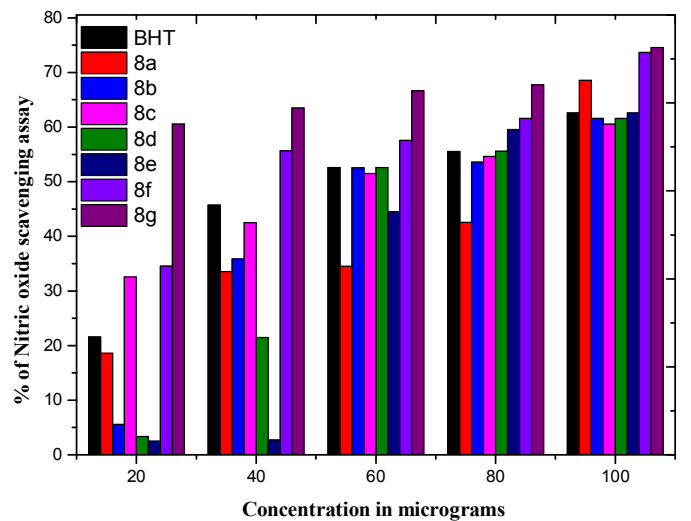

Fig. 3. Nitric oxide assay of the synthesized compounds

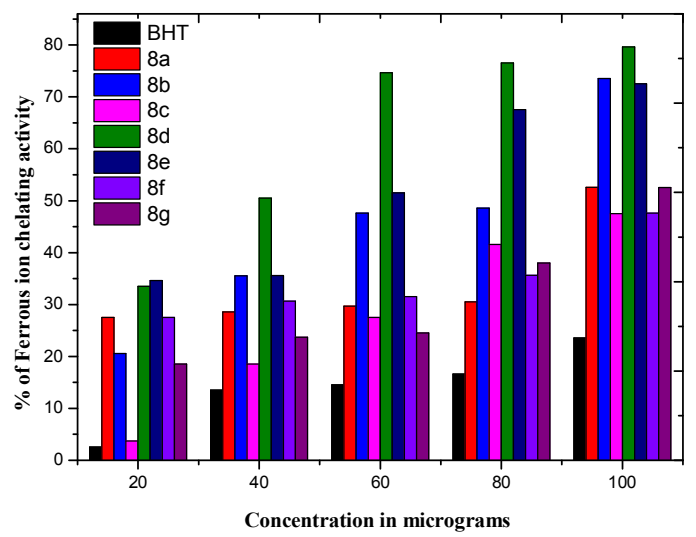

Fig. 4. Ferrous ion assay of the synthesized compounds

\subsubsection{Ferrous ion chelating ability}

Iron is known to generate free radicals through the Fenton and Haber-Weiss reactions. ${ }^{28}$ Metal ion chelating activity of an antioxidant molecule prevents oxy-radical generation and consequent oxidative damage. Metal ion-chelating capacity plays a significant role in anti-oxidant mechanism since it reduces the concentration of the catalyzing transition metal in lipid peroxidation. It is reported that chelating agents, which form sigma-bonds with a metal, are effective as secondary antioxidants because they decrease the redox potential of the metal centre, thereby stabilizing the oxidized form of the metal ion. ${ }^{29}$ By virtue of both metal chelating properties and radical scavenging ability, compounds $\mathbf{8 a - 8 g}$ may have a role in the prevention of free radicals with $\mathrm{IC}_{50}$ values ranging from $39.59 \mu \mathrm{g} / \mathrm{mL}$ for $\mathbf{8 d}$ to $105.60 \mu \mathrm{g} / \mathrm{mL}$ for $\mathbf{8 c}\left(\mathrm{BHT} \mathrm{IC}_{50}\right.$ value $\left.=213.45 \mu \mathrm{g} / \mathrm{mL}\right)$.

\subsection{Antiangiogenic activity}

Anti-angiogenic treatment is one of the main methods of tumor treatment and control of pathological angiogenesis. ${ }^{30}$ Pathological angiogenesis is regulated by targeting integrins, which are predominantly expressed in most of the tumor cells and endothelial cells of blood vessels. The interaction of vascular endothelial growth factor (VEGF) and its receptors in a signal transduction pathway also regulates angiogenesis. ${ }^{31}$

In the present investigation, some of the compounds among $\mathbf{8 a - 8 g}$ reduced the proliferation of blood vessels in the shell-less CAM assay model with developing embryos. The proliferation of microvessels 
was repressed only in group treated with compounds $8 \mathbf{b}, \mathbf{8 d}, \mathbf{8 e}, \mathbf{8 f}$ and $\mathbf{8 g}$ (Fig. 5) supporting their antiangiogenic activity.

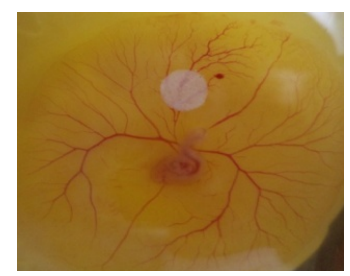

Control

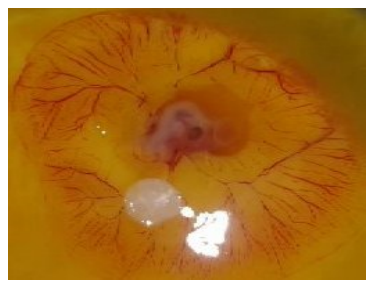

$8 \mathbf{e}$

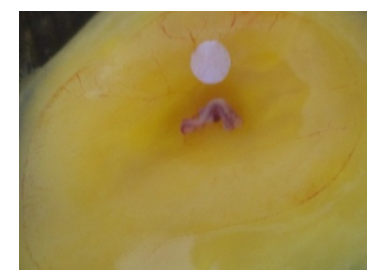

$\mathbf{8 b}$

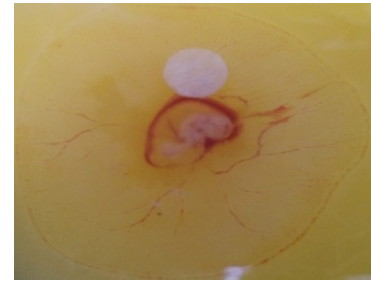

8f

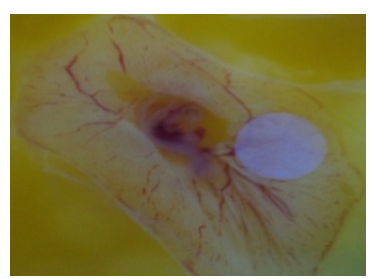

8d

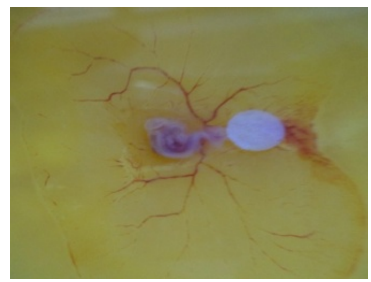

$8 g$

Fig. 5. Inhibition of angiogenesis in vivo of 1,5-benzothiazepin-4-(5H)-ones $(\mathbf{8 a}-\mathbf{8 g})$ in shell- less CAM assay.

\section{Conclusion}

In the present study, novel 1,5-benzothiazepin-4(5H)-one derivatives have been synthesized and their antioxidant and antiangiogenic activities have been assessed. Oxidative stress and angiogenesis are important biological mechanisms by which tumorgenesis and tumor progression occur. Antiangiogenic determined in the shell-less CAM model revealed that $\mathbf{8 b}, \mathbf{8 d}, \mathbf{8 e}, \mathbf{8 f}$ and $\mathbf{8 g}$ compounds are endowed with interesting anti-tumor activities. Further, antioxidants have proved to protect against oncogenic transformations resulting from radiation and free-radicals in experimental systems. ${ }^{31}$ The significant multiple antioxidant activities of 1,5-benzothiazepin-4 $(5 \mathrm{H})$-one derivatives, especially the high ferrous ion chelating ability of 8a-8g and nitric oxide radical scavenging activity of $\mathbf{8 f}$ and $\mathbf{8 g}$, appear to protect the cells by neutralizing or trapping reactive oxygen species and other free radicals. These results conclusively prove that rational design of 1,5-benzothiazepin- $4(5 \mathrm{H})$-one derivatives can be used to create anti-angiogenic and antioxidant agents.

\section{Acknowledgements}

DGB acknowledges UGC vide NO. F. No. 41-316/2012 (SR) dated 01.07.2012 for the financial support.

\section{Experimental}

\subsection{General}

All reagents were purchased from Sigma Aldrich Chemicals. Infrared (IR) spectra were recorded on a JASCO FT/IR-4100 spectrophotometer in $\mathrm{KBr}$ disc for solid compounds and nujol for liquids and are reported in reciprocal wave number $\left(\mathrm{cm}^{-1}\right)$. ${ }^{1} \mathrm{H}$ NMR spectra were recorded in DMSO- $\mathrm{d}_{6}$ at 300 and $400 \mathrm{MHz}$. The following abbreviations are used for structural assignments of ${ }^{1} \mathrm{H}$ NMR: s, singlet; d, doublet; t, triplet; dd, doublet of doublets; m, multiplet and br, broad. Mass and purity were recorded on a LC-MSD-Trap-XCT. Thin layer chromatography was performed using 600 mesh silica gel plates, and visualization was effected with short wavelength UV light $(254 \mathrm{~nm})$. All other commercial reagents were used as received. 


\subsection{General procedure for the synthesis of Ethyl-[2-n-butyl-2-hydroxy methyl]hexanoate (2)}

Diethyl di- $n$-butyl malonate $(25 \mathrm{~g}, 0.090 \mathrm{~mol})$ was dissolved in toluene $(143 \mathrm{~mL})$ under $\mathrm{N}_{2}$ atmosphere and cooled to -60 to $-70{ }^{\circ} \mathrm{C}$. DIBAL-H $(25 \%$ in toluene, $31.3 \mathrm{~g}, 0.22 \mathrm{~mol})$ solution was added at this temperature over $15 \mathrm{~min}$, then stirred for $4 \mathrm{~h}$. Absolute ethanol $(177 \mathrm{~mL})$ was added slowly at -40 to $-50{ }^{\circ} \mathrm{C}$ and the temperature was raised to $0{ }^{\circ} \mathrm{C}$. $\mathrm{NaBH}_{4}(3.49 \mathrm{~g}, 0.090 \mathrm{~mol})$ was added portionwise below $0{ }^{\circ} \mathrm{C}$ and the reaction mixture was stirred at room temperature for $1 \mathrm{~h}$, cooled to $15-20{ }^{\circ} \mathrm{C}$, and saturated $\mathrm{Na}_{2} \mathrm{SO}_{4}$ solution was added. The reaction mass was stirred for $1 \mathrm{~h}$, filtered through celite bed, extracted with ethyl acetate $(25 \mathrm{~mL} \times 2)$, washed with brine, dried over sodium sulfate and concentrated under vacuum at $50-55{ }^{\circ} \mathrm{C}$ to afford the title compound 2 as a thick syrup.

Pale yellow liquid, yield 19.0 g, 76\%; FT-IR (Paraffin) v/ $\mathrm{cm}^{-1}: 3617,2857,1739 ;{ }^{1} \mathrm{H} \mathrm{NMR} \mathrm{(400} \mathrm{MHz,}$ DMSO-d $\left.{ }_{6}\right): \delta=4.56(\mathrm{t}, 1 \mathrm{H}, \mathrm{J}=4.8), 4.01(\mathrm{q}, 2 \mathrm{H}, \mathrm{J}=7.2), 3.42(\mathrm{~d}, 2 \mathrm{H}, \mathrm{J}=5.2), 1.36-1.49(\mathrm{~m}, 8 \mathrm{H})$, $1.18(\mathrm{t}, 4 \mathrm{H}, \mathrm{J}=7.2), 0.80(\mathrm{t}, 6 \mathrm{H}, \mathrm{J}=8.6) ; \mathrm{MS}(\mathrm{ES}) \mathrm{m} / \mathrm{z}(\mathrm{m}+1): 244.3$

\subsection{General procedure for the synthesis of Ethyl-[2-n-butyl-2-hydroxy methyl]hexanoic acid (3)}

To a stirred solution of ethyl-[2-n-butyl-2-hydroxymethyl]hexanoate (15.0 g, $0.0652 \mathrm{~mol})$ in methanol $(67.5 \mathrm{~mL})$, was added $\mathrm{NaOH}(5.86 \mathrm{~g}, 0.146 \mathrm{~mol})$ as a solution and the resulting mixture refluxed for $17 \mathrm{~h}$. The methanol was distilled off at $55-60{ }^{\circ} \mathrm{C}$ under vacuum, cooled to room temperature and washed with petroleum ether. Aqueous layer was taken back to the reactor, cooled to $10-15^{\circ} \mathrm{C}$ and acidified with concentrated $\mathrm{HCl}$ to $\mathrm{pH} 2$. The mixture was extracted with dichloromethane $(25 \mathrm{~mL} \times$ 2 ) and washed with brine solution. The organic layer was dried over sodium sulfate and concentrated under vacuum at $40-45^{\circ} \mathrm{C}$ to yield a thick syrup.

Pale yellow liquid, yield $13.73 \mathrm{~g}$, 92\%; FT-IR (Paraffin) v/ $\mathrm{cm}^{-1}: 2857,3359,2857 ;{ }^{1} \mathrm{H} \mathrm{NMR}$ (400 MHz, DMSO-d $)_{6}: \delta=11.94(\mathrm{~s}, 1 \mathrm{H}), 3.40(\mathrm{~d}, 2 \mathrm{H}, \mathrm{J}=4.8), 1.34-1.46(\mathrm{~m}, 8 \mathrm{H}), 1.24(\mathrm{t}, 4 \mathrm{H}, \mathrm{J}=7.2), 0.80(\mathrm{t}$, $6 \mathrm{H}, \mathrm{J}=8.6) ; \mathrm{MS}(\mathrm{ES}) \mathrm{m} / \mathrm{z}(\mathrm{m}+1): 203.3$

\subsection{General procedure for the synthesis of 2-Bromomethyl-2-n-butylhexanoic acid (4)}

To a solution of $48 \%$ (aq.) hydrobromic acid was added slowly concentrated $\mathrm{H}_{2} \mathrm{SO}_{4}$ below $25{ }^{\circ} \mathrm{C}$ over a period of $1 \mathrm{~h}$ and then added $2(10 \mathrm{~g}, 0.049 \mathrm{~mol})$. The reaction mixture was heated to $90-95^{\circ} \mathrm{C}$ and maintained at this temperature for $16 \mathrm{~h}$. The reaction was then cooled to $15-20{ }^{\circ} \mathrm{C}$ and extracted with dichloromethane $(25 \mathrm{~mL} \times 2)$. The organic layer was concentrated under vacuum at $40-45{ }^{\circ} \mathrm{C}$, then the residue was distilled using a high vacuum pump. Product distilled at $140-160{ }^{\circ} \mathrm{C} / 1 \mathrm{~mm} \mathrm{Hg}$.

Pale yellow liquid, yield $4.36 \mathrm{~g}$, 35\%; FT-IR (Paraffin) $\mathrm{v} / \mathrm{cm}^{-1}: 2857,2923,512 ;{ }^{1} \mathrm{H}$ NMR (400 MHz, DMSO-d $\left._{6}\right): \delta=12.62(\mathrm{~s}, 1 \mathrm{H}), 3.58(\mathrm{~s}, 1 \mathrm{H}), 1.46-1.59(\mathrm{~m}, 4 \mathrm{H}), 1.19-1.28(\mathrm{~m}, 8 \mathrm{H}), 0.80(\mathrm{t}, 6 \mathrm{H}, \mathrm{J}=$ 8.6); MS (ES) m/z (m+1): 266.2

4.5. General procedure for the synthesis of 2-\{[(2-Amino-5-methoxyphenyl)thio]methyl\}-2-nbutylhexanoic acid (6)

To a stirred solution of amino-6-methoxy benzothiazole $(4.00 \mathrm{~g}, 0.022 \mathrm{~mol})$ in water $(44 \mathrm{~mL})$ was added $\mathrm{KOH}$ (12.4 g, $0.22 \mathrm{~mol})$. The reaction mixture was refluxed for $16 \mathrm{~h}$ under $\mathrm{N}_{2}$ atmosphere. It was then cooled to $15^{\circ} \mathrm{C}$ and added $3(7.63 \mathrm{~g}, 0.028 \mathrm{~mol})$ in THF $(9.48 \mathrm{~mL})$ slowly over a period of 30 min and then allowed the reaction mass to come to $20-25{ }^{\circ} \mathrm{C}$ and stirred for $10 \mathrm{~h}$ and then refluxed at $60-65{ }^{\circ} \mathrm{C}$ for $2 \mathrm{~h}$. It was then cooled to $20-25{ }^{\circ} \mathrm{C}$ and diluted with water. The reaction was then adjusted to $\mathrm{pH} 5$ using $1.5 \mathrm{~N} \mathrm{HCl}$, diluted with water and extracted with DCM $(25 \mathrm{~mL} \times 2)$. The organic layer was washed with water and then with brine, dried over sodium sulfate and solvent was removed under reduced pressure to yield a thick syrup.

Dark brown liquid, yield 3.6 g, 90\%; FT-IR (Paraffin) v/cm ${ }^{-1}: 3363,3189,2923,2857 ;{ }^{1} \mathrm{H}$ NMR (400 MHz, DMSO-d 6 ): $\delta=6.83(\mathrm{~s}, 1 \mathrm{H}), 6.64$ (dd, $2 \mathrm{H}, \mathrm{J}=2.8,0.4), 3.60$ (s, $3 \mathrm{H}), 2.95$ (s, $2 \mathrm{H}), 1.48-$ $1.56(\mathrm{~m}, 4 \mathrm{H}), 1.13(\mathrm{t}, 4 \mathrm{H}, \mathrm{J}=6.4), 1.20(\mathrm{t}, 4 \mathrm{H}, \mathrm{J}=5.6), 0.80(\mathrm{t}, 6 \mathrm{H}, \mathrm{J}=8.6)$; MS (ES) m/z (m+1): 340.3 
4.6. General procedure for the synthesis of 3,3-di-n-butyl-8-methoxy-2,3-dihydro-1,5benzothiazepin-4-(5H)-one (7):

To a stirred solution of $4(3.00 \mathrm{~g}, 0.0088 \mathrm{~mol})$ in ethyl acetate $(27 \mathrm{~mL})$, was added triethylamine $(1.95 \mathrm{~g}, 0.0193 \mathrm{~mol})$. The reaction mixture was cooled to $0{ }^{\circ} \mathrm{C}$ and $\mathrm{T}_{3} \mathrm{P}(2.81 \mathrm{~g}, 0.0088 \mathrm{~mol})$ added at $0{ }^{\circ} \mathrm{C}$, then stirred at $25^{\circ} \mathrm{C}$ for $3 \mathrm{~h}$ and diluted with ethyl acetate. The above organic layer was washed with $10 \% \mathrm{NaHCO}_{3}$ solution, then water, brine, dried over sodium sulfate and concentrated under vacuum at $50{ }^{\circ} \mathrm{C}$ to obtain a crude product which was purified by chromatography on silica gel using ethyl acetate and hexane.

Brown solid, yield $3.6 \mathrm{~g}, 90 \%$; FT-IR $(\mathrm{KBr}) \mathrm{v} / \mathrm{cm}^{-1}: 3092,2867,1213,1644 ;{ }^{1} \mathrm{H}$ NMR (400 MHz, DMSO-d $\left.)_{6}\right): \delta=9.48(\mathrm{~s}, 1 \mathrm{H}), 7.00(\mathrm{~d}, 1 \mathrm{H}, \mathrm{J}=8.4), 6.93(\mathrm{~d}, 1 \mathrm{H}, \mathrm{J}=2.8), 6.82(\mathrm{q}, 1 \mathrm{H}, \mathrm{J}=2.8), 3.69$ $(\mathrm{s}, 3 \mathrm{H}), 2.94(\mathrm{~s}, 2 \mathrm{H}), 1.39-1.46(\mathrm{~m}, 4 \mathrm{H}), 1.14-1.39(\mathrm{~m}, 8 \mathrm{H}), 0.80(\mathrm{t}, 6 \mathrm{H}, \mathrm{J}=8.6)$; MS (ES) m/z $(\mathrm{m}+1): 322.0$.

4.7. General procedure for the synthesis of 3,3-Dibutyl-8-methoxy-5-alkyl-2,3-dihydro-5Hbenzo[b][1,4]thiazepin-4-one (8)

A solution of $5(0.20 \mathrm{~g}, 0.62 \mathrm{mmol})$ in DMF $(3 \mathrm{~mL})$ was cooled to $0{ }^{\circ} \mathrm{C}$ under $\mathrm{N}_{2}$ atmosphere and $\mathrm{NaH}(0.0223 \mathrm{~g}, 0.933 \mathrm{mmol})$ added and stirred for $15 \mathrm{~min}$. To this reaction mixture, methyl iodide $(0.0425 \mathrm{~mL})$ was added and the reaction mixture allowed to stir for one hour at room temperature. Progress of the reaction was monitored by TLC. When the reaction was complete, the reaction mixture was diluted with water $(30 \mathrm{~mL})$ and extracted with ethyl acetate $(25 \mathrm{~mL} \times 2)$. The organic layer was dried over anhydrous sodium sulfate, and concentrated under vacuum to afford a crude product, which was purified by chromatography on silica gel using ethyl acetate and hexane.

\subsubsection{3,3-Dibutyl-8-methoxy-5-methyl-2,3-dihydro-5H-benzo[b][1,4]thiazepin-4-one (8a)}

Colorless semi-solid, ${ }^{1} \mathrm{H}$ NMR (400 MHz, DMSO-d 6$): \delta=7.30(\mathrm{~d}, 1 \mathrm{H}, \mathrm{J}=11.72), 7.10(\mathrm{~d}, 1 \mathrm{H}, \mathrm{J}$ = 3.84), 7.03 (q, $1 \mathrm{H}, \mathrm{J}=7.76,3.88), 3.75(\mathrm{~s}, 3 \mathrm{H}), 3.17(\mathrm{~s}, 3 \mathrm{H}), 3.00(\mathrm{~s}, 2 \mathrm{H}), 1.06-1.34(\mathrm{~m}, 12 \mathrm{H}), 0.78$ (t, $3 \mathrm{H}, \mathrm{J}=8.6) ; \mathrm{MS}(\mathrm{ES}) \mathrm{m} / \mathrm{z}(\mathrm{m}+1): 336.4$

4.7.2. 3,3-Dibutyl-5-ethyl-8-methoxy-2,3-dihydro-5H-benzo[b][1,4] thiazepin-4-one (8b)

Colorless semi-solid; ${ }^{1} \mathrm{H}$ NMR (400 MHz, DMSO-d 6 ): $\delta=7.33(\mathrm{~d}, 1 \mathrm{H}, \mathrm{J}=8.8), 7.13(\mathrm{~d}, 1 \mathrm{H}, \mathrm{J}=2.96$ ), $7.03(\mathrm{q}, 1 \mathrm{H}, \mathrm{J}=8.8,3.00), 3.78(\mathrm{~s}, 3 \mathrm{H}), 3.01(\mathrm{~s}, 2 \mathrm{H}), 1.00-1.26(\mathrm{~m}, 16 \mathrm{H}), 0.78(\mathrm{t}, 6 \mathrm{H}, \mathrm{J}=8.6)$; MS (ES) $\mathrm{m} / \mathrm{z}(\mathrm{m}+1): 350.4$.

\subsubsection{5-Allyl-3,3-dibutyl-8-methoxy-2,3-dihydro-5H-benzo[b][1,4]thiazepin-4-one (8c)}

Colorless semi-solid; ${ }^{1} \mathrm{H}$ NMR (400 MHz, DMSO- $\left.{ }_{6}\right): \delta=7.32(\mathrm{~d}, 1 \mathrm{H}, \mathrm{J}=8.8), 7.12(\mathrm{~d}, 1 \mathrm{H}, \mathrm{J}=$ 2.92), 7.04 (q, $1 \mathrm{H}, \mathrm{J}=8.8,2.96), 5.7-5.86(\mathrm{~m}, 1 \mathrm{H}), 5.14(\mathrm{~d}, 1 \mathrm{H}, \mathrm{J}=1.36), 5.10(\mathrm{~d}, 1 \mathrm{H}, \mathrm{J}=1.32)$, 4.34 (s, 2 H), 3.77 (s, 3 H), 3.03 (s, 2 H), 1.32-1.37 (m, 12 H); MS (ES) m/z (m+1): 362.4.

4.7.4. 3,3,5-Tributyl-8-methoxy-2,3-dihydro-5H-benzo[b][1,4]thiazepin-4-one $(\mathbf{8 d})$

Colorless semi-solid ${ }^{1} \mathrm{H}$ NMR (400 MHz, DMSO-d 6$): \delta=7.32(\mathrm{~d}, 1 \mathrm{H}, \mathrm{J}=8.8), 7.12(\mathrm{~d}, 1 \mathrm{H}, \mathrm{J}=2.8)$, 7.03 (q, $1 \mathrm{H}, \mathrm{J}=8.8,2.40), 3.77(\mathrm{~s}, 3 \mathrm{H}), 3.00$ (s, $2 \mathrm{H}), 1.16-1.41(\mathrm{~m}, 8 \mathrm{H}), 1.04-1.16(\mathrm{~m}, 9 \mathrm{H}), 0.85$ (t, $9 \mathrm{H}, \mathrm{J}=5.6)$; MS (ES) $\mathrm{m} / \mathrm{z}(\mathrm{m}+1): 378.4$.

\subsubsection{3,3-Dibutyl-5-isobutyl-8-methoxy-2,3-dihydro-5H-benzo[b][1,4]thiazepin-4-one (8e)}

Colorless semi-solid ${ }^{1} \mathrm{H}$ NMR (400 MHz, DMSO-d 6 ): $\delta=7.34(\mathrm{~d}, 1 \mathrm{H}, \mathrm{J}=8.8), 7.13(\mathrm{~d}, 1 \mathrm{H}, \mathrm{J}=$ 2.96), 7.04 (q, 1 H, J = 8.8, 3.0), 3.77 (s, 3 H), 3.04 (s, 2 H), 1.77 (m, 1 H); MS (ES) m/z (m+1): 378.3.

\subsubsection{2-(3,3-Dibutyl-8-methoxy-4-oxo-3,4-dihydro-2H-benzo[b][1,4]thiazepin-5-yl)-N-isopropyl- acetamide (8f)}

Off-white solid ${ }^{1} \mathrm{H}$ NMR (400 MHz, DMSO- $\left.\mathrm{d}_{6}\right): \delta=7.66(\mathrm{~d}, 1 \mathrm{H}, \mathrm{J}=7.2), 7.42(\mathrm{~d}, 1 \mathrm{H}, \mathrm{J}=8.8), 7.03$ $(\mathrm{q}, 1 \mathrm{H}, \mathrm{J}=8.8,3.2), 3.8(\mathrm{~m}, 1 \mathrm{H}), 3.76(\mathrm{~s}, 3 \mathrm{H}), 3.03(\mathrm{~s}, 2 \mathrm{H}), 1.22-1.34(\mathrm{~m}, 14 \mathrm{H}), 1.00(\mathrm{~d}, 6 \mathrm{H}, \mathrm{J}=$ 6.4), 0.77 (t, $6 \mathrm{H}, \mathrm{J}=5.6)$; MS (ES) $\mathrm{m} / \mathrm{z}(\mathrm{m}+1)$ : 421.4 . 
4.7.7. 3,3-Dibutyl-8-methoxy-5(2-piperidin-1-yl-ethyl)2,3-dihydro-5H-benzo[b][1,4]thiazepin-4-one $(8 g)$

Yellow semi-solid ${ }^{1} \mathrm{H}$ NMR (400 MHz, DMSO-d 6 ): $\delta=7.55(\mathrm{~d}, 1 \mathrm{H}, \mathrm{J}=11.72), 7.08(\mathrm{~d}, 1 \mathrm{H}, \mathrm{J}=$ 3.76), 7.04 (q, $1 \mathrm{H}, \mathrm{J}=7.8,3.8), 3.75$ (s, $3 \mathrm{H}), 2.97$ (s, $2 \mathrm{H}), 2.25(\mathrm{~m}, 4 \mathrm{H}), 1.01-1.40$ (m, $26 \mathrm{H}), 0.77$ (t, $6 \mathrm{H}, \mathrm{J}=5.6)$; MS (ES) $\mathrm{m} / \mathrm{z}(\mathrm{m}+1)$ : 433.4 .

\subsection{Antioxidant activities}

\subsubsection{DPPH radical scavenging assay}

DPPH radical scavenging activity was carried out according to the method of Scherer et al.. ${ }^{32}$ Briefly, DPPH solution ( $1 \mathrm{~mL}, 0.1 \mathrm{mM}$ in $95 \%$ ethanol) was mixed with different aliquots of 8a-8g. After vigorous shaking, the mixture was allowed to stand for $20 \mathrm{~min}$ at room temperature. Absorbance of the resulting solution was measured at $517 \mathrm{~nm}$ with a UV-VIS spectrophotometer (HITACHI, U2900). Butylated hydroxyl toluene (BHT) was used as positive control. Radical scavenging potential is expressed as $\mathrm{IC}_{50}$ value, which represents the sample concentration at which $50 \%$ of DPPH radicals are scavenged.

\subsubsection{Hydroxyl radical scavenging assay}

The reaction mixture containing different aliquots of $\mathbf{8 a - 8 g}$, deoxyribose $(10 \mathrm{mM}), \mathrm{H}_{2} \mathrm{O}_{2}(10 \mathrm{mM})$, $\mathrm{FeCl}_{3}(5 \mathrm{mM})$, EDTA $(1 \mathrm{mM})$ and ascorbic acid $(5 \mathrm{mM})$ in potassium phosphate buffer $(50 \mathrm{mM}, \mathrm{pH}$ 7.4) was allowed to stand for $60 \mathrm{~min}$ at $37^{\circ} \mathrm{C} .{ }^{33}$ The reaction was terminated by adding TCA $(5 \% \mathrm{~W} / \mathrm{V})$ and the reaction product was measured by reaction with TBA $(0.2 \% \mathrm{~W} / \mathrm{V})$ in boiling water bath for 15 min. The absorbance was measured at $535 \mathrm{~nm}$ against the reagent blank and inhibition of the oxidation of deoxyribose was calculated against the control using UV-VIS spectrophotometer (HITACHI, U2900). BHT was used as positive control and radical scavenging potential was expressed as $\mathrm{IC}_{50}$ value.

\subsubsection{Nitric oxide radical scavenging activity}

Nitric oxide was generated from sodium nitroprusside and measured by Griess reaction. Sodium nitroprusside in phosphate buffer at physiological $\mathrm{pH}$ spontaneously generates nitric oxide, which in turn reacts with oxygen to produce nitrite ions that can be estimated by the Griess reagent. ${ }^{34}$ Nitric oxide scavengers compete with oxygen, leading to reduced production of nitric oxide. Sodium nitroprusside $(5 \mathrm{mM})$ in phosphate buffered saline was mixed with different aliquots of $\mathbf{8 a - 8 g}$ and incubated at $25^{\circ} \mathrm{C}$ for $3 \mathrm{~h}$. The absorbance of the color formed during the diazotization of nitrite with sulphanilamide and subsequent coupling with napthylethylenediamine was read at $546 \mathrm{~nm}$ and referred with the absorbance of BHT treated in the same way with the Griess reagent. The radical scavenging potential was calculated and expressed as $\mathrm{IC}_{50}$ value.

\subsubsection{Ferrous ion chelating ability}

Ferrous ion chelating ability was measured according to the method of Suter and Richter. ${ }^{35}$ Three sets of test tubes were taken; the first tube as control: To this $40 \mu \mathrm{L}$ of $\mathrm{FeCl}_{3}(200 \mu \mathrm{M})$ and $80 \mu \mathrm{L}$ of $\mathrm{K}_{3} \mathrm{Fe}(\mathrm{CN})_{6}(400 \mathrm{mM})$ were added and the volume was made up to $1 \mathrm{~mL}$ by adding distilled water. For the second tube $20 \mu \mathrm{L}$ of EDTA $(400 \mathrm{mM}), 40 \mathrm{~mL}$ of $\mathrm{FeCl}_{3}$ and $80 \mu \mathrm{L} \mathrm{K} 3 \mathrm{Fe}(\mathrm{CN})_{6}$ were added and the volume was made up to $1 \mathrm{~mL}$ by adding distilled water. For the third sample $(10 \mu \mathrm{g}-100 \mu \mathrm{g}), 40 \mu \mathrm{L}$ of $\mathrm{FeCl}_{3}$ and $80 \mu \mathrm{L}$ of $\mathrm{K}_{3} \mathrm{Fe}(\mathrm{CN})_{6}$ were added and the volume was made up to $1 \mathrm{~mL}$ by adding distilled water. The tubes were incubated for $10 \mathrm{~min}$ at $20^{\circ} \mathrm{C}$ and the $\mathrm{OD}$ read at $700 \mathrm{~nm}$. The assay was carried out at $20{ }^{\circ} \mathrm{C}$ to prevent $\mathrm{Fe}^{2+}$ oxidation. 


\subsection{Antiangiogenic activity}

Fertilized eggs were obtained from IVRI, Bangalore, India. All chemicals were purchased from Sisco Research Laboratories, Mumbai, India and they were of analytical grade. Antiangiogenic effects of $\mathbf{8 a - 8 g}$ compounds was studied according to the method of Auerbach et al. ${ }^{36}$. Briefly, fertilized hens eggs were surface sterilized using $70 \%$ alcohol. The eggs were incubated in fan assisted humidified incubator at $37^{\circ} \mathrm{C}$. On the $4^{\text {th }}$ day, the eggs were cracked out into thin films of the hammock within a laminar flow cabinet and were further incubated. On day $5^{\text {th }}$ when blood vessels were seen proliferating from the center of the eggs within the hammock, filter paper discs loaded with $100 \mu \mathrm{g}$ of the compounds 8a-8g were placed over the proliferating blood vessels and the eggs were returned to the incubator. Results of antiangiogenic effects of the compounds were noted after $24 \mathrm{~h}$.

\section{References}

1. Wu H.; Chen H.; Sun Y.; Wan Y.; Wang F.; Ji B.; Su X. (2013) Imaging integrin $\alpha(v) \beta(3)$ positive glioma with a novel RGD dimer probe and the impact of antiangiogenic agent (Endostar) on its tumor uptake. Cancer Lett., 335, 75-80.

2. Jeon K. S.; Na H-J.; Kim Y-M.; Kwon H. J. (2005) Antiangiogenic activity of 4-O-methylgallic acid from Canavalia gladiata, a dietary legume. Biochem. Biophys. Res. Commun., 330, 1268 1274.

3. Gangjee A., Kurup S., Ihnat M. A., Thorpe J. E., Shenoy S. S. (2010) Synthesis and biological activity of N4-phenylsubstituted-6-(2,4-dichloro phenylmethyl)-7H-pyrrolo[2,3-d]pyrimidine2,4-diamines as vascular endothelial growth factor receptor-2 inhibitors and antiangiogenic and antitumor agents. Bioorg. Med. Chem., 18, 3575-3587.

4. Shenvi S., Kumar K., Hatti K. S., Rijesh K.; Diwakar L., Reddy G. C. (2013) Synthesis, anticancer and antioxidant activities of 2,4,5-trimethoxy chalcones and analogues from asaronaldehyde: Structureeactivity relationship. Eur. J. Med. Chem., 62, 435-442.

5. Cunha C. R. M. D., Neto S. A. M., Silva C. C. D., Cortez A. P., Gomes M. D. N., Martins F. I., Alonso A., Rezende K. R., Menegatti R., M. T. Q. D. Magalhães M. T. Q. D., Valadares M. C. (2013) 4-Nerolidylcatechol and its synthetic analogues: Antioxidant activity and toxicity evaluation. Eur. J. Med. Chem., 62, 371-378.

6. Andreani A., Leoni A., Locatelli A., Morigi R., Rambaldi M., Rinaldo, Cervellati, Greco, E., Kondratyuk, T. P., Park, E-J., Huang, K., Breemend. R. B. V., Pezzuto, J. M. (2013) Chemopreventive and antioxidant activity of 6-substituted imidazo[2,1-b]thiazoles. Eur. J. Med. Chem., 68, 412-421.

7. Atwal K. S., Ahmed S. Z., Floyd D. M., Moreland S., Hedberg A. (1993) (cis)-3-methyl-1,5benzothiazepine-4-ones: potent analogs of the calcium channel blocker diltiazen. Bioorg. Med. Chem. Lett., 12, 2797-2800.

8. Itoh K., Kori M., Inada Y., Nishikawa K., Kawamatsu Y., Sugihara H. (1986) Synthesis and angiotensin converting enzyme inhibitory activity of 1,5-benzothiazepine and 1,5-benzoxazepine derivatives. Chem Pharm Bull., 34(5), 2078-2089.

9. Sarro G. D., Chimirri A., Sarro A. D., Gitto R., Grasso S., Zappala M. (1995) 5H$[1,2,4]$ Oxadiazolo[5,4- $d][1,5]$ benzothiazepines as anticonvulsant agents in DBA/2 mice. Eur. $J$. Med. Chem., 30, 925-929.

10. Grandolini G., Perioli L., Ambrogi V. (1999) Synthesis of some new 1,4-benzothiazine and 1,5benzothiazepine tricyclic derivatives with structural analogy with TIBO and their screening for anti-HIV activity. Eur. J. Med. Chem., 34, 701-709.

11. Ham W-H., Yang J-G., Lim T. G., Jung Y-H. (1994) Synthesis of antihypertensive agents via coupling reaction of Benzothiazepinone and 1,4-dihydropyridine derivatives. Archives of Pharmacal Research., 17, 119-123. 
12. Dumont L., Libersan D., Chartrand C., Levy E., Garceau D. (1990) Inhibition of platelet aggregation by a new 1.5-benzothiazepine calcium antagonist, TA-3090. Eur. J. Pharmacol., 183, 638.

13. Kapil A., Anshu D. (2008) The expedient synthesis of 1,5-benzothiazepines as a family of cytotoxic drugs. Bioorg. Med. Chem. Lett., 18, 114-119.

14. Wang L., Zhang P., Zhang X., Zhang Y., Li Y., Wang Y. (2009) Synthesis and biological evaluation of a novel series of 1,5-benzothiazepine derivatives as potential antimicrobial agents. Eur. J. Med. Chem., 44, 2815-2821.

15. Mor S., Pahal, P., Narasimhan B. (2012) Synthesis, characterization, biological evaluation and QSAR studies of 11-p-substituted phenyl-12-phenyl-11a,12-dihydro-11H-indeno[2,1c][1,5]benzothiazepines as potential antimicrobial agents. Eur. J. Med. Chem., 57, 196-210.

16. Amblard M., Daffix I., Bedos P., Berge G., Pruneau D., Paquet J-L., Luccarini J-M., Lichard P. B., Dodey P., Martinez J. (1999) Design and synthesis of potent bradykinin agonists containing a benzothiazepine moiety. J. Med. Chem., 42, 4185-4192.

17. Phippen C. B. W., McErlean C. S. P. (2011) A 1,5-benzothiazepine synthesis. Tetrahedron Letters., 52, 1490.

18. Micheli F., Degiorgis F., Feriani A., Paio A., Pozzan A., Zarantonello P., Seneci P. (2001) A Combinatorial Approach to [1,5]Benzothiazepine Derivatives as Potential Antibacterial Agents. $J$. Comb. Chem., 3, 224-228.

19. Akbarzadeh R., Amanpour T., Khavasi H. R., Bazgir. A. (2014) Atom-economical isocyanidebased multicomponent synthesis of 2,5-dioxopyrrolidines, spirobenzothiazinechromans and 1,5benzothiazepines. Tetrahedron., 70, 169-173.

20. (a) David M. F., Robert V. M., Karnail S. A., Syed Z. A., Steven H. S., Jack Z. G., Mary F. M. (1990) Synthesis of Benzazepinone and 3-Methylbenzothiazepinone Analogues of Diltiazem. $J$. Org. Chem., 55, 5572-5579. (b) Balasubramaniyan V., Balasubramaniyan P., Shaikh A. S. (1986) Reactions of $o$-aminothiophenol with $\alpha, \beta$-unsaturated dicarbonyl systems, facile synthesis of benzothiazines and benzothiazepines. Tetrahedron., 42, 2731-2738.

21. Slade J., Stanton J. L., Ben-David D., Mazzenga G. C. (1985) Angiotensin converting enzyme inhibitors: 1,5-benzothiazepine derivatives. J. Med. Chem., 28, 1517-1521.

22. Revanna C. N., Raghavendra G. M., Jenifer Vijay T. A., Rangappa K. S., Bhadregowda D. G., Mantelingu K. (2014) Propylphosphonic anhydride-catalyzed tandem approach for biginelli reaction starting from alcohols. Chemistry Letters, 43, 178-180.

23. Revanna C. N., Basappa., Srinivasan V., Feng Li., Kodappully S. S., Xiaoyun D., Shivananju N. S., Bhadregowda D. G., Gautam S., Mantelingu K., Andreas B., Rangappa K. S. (2014) Synthesis and biological evaluation of tetrahydropyridinepyrazoles ('PFPs') as inhibitors of STAT3 phosphorylation. Journal of the European Federation for Medicinal Chemistry., 5, 32-40.

24. Yamaguchi T., Takamura H., Matoba T., Terao J. (1998) HPLC method for evaluation of free radical-scavenging activity of foods by using 1,1-diphenyl-1-2-picrylhydrazyl. Biosci. Biotechnol. Biochem., 62, 1201-1204.

25. Hochestein P., Atallah A.S. (1988) The nature of oxidant and antioxidant systems in the inhibition of mutation and cancer. Mutat. Res., 202, 363-375.

26. Moncada A, Palmer R. M. J., Higgs E. (1991) Nitric oxide: physiology, pathophysiology and pharmacology. Pharmacol Rev., 43, 109-142.

27. Rojas-Walker T. D., Tamir S., Ji, H., Wishnok J. S., Tannenbaum S. R. (1995) Chem. Res. Toxicol., $8,473-477$.

28. Gutteridge J. M.; Halliwell B. (1990) Reoxygenation injury and antioxidant protection: a tale of two paradoxes. Arch Biochem Biophys., 283, 223-226.

29. Gordon M. H. (1990) The mechanism of antioxidant action in vitro. in Hudson BJF, ed. Food antioxidants. Elsevier Applied Science, London. pp. 1-18. 
30. Los M., Roodhart J. M., Voest E. E. (2007) Target practice: lessons from phase III trials with bevacizumab and vatalanib in the treatment of advanced colorectal cancer. Oncologist., 12, 443450 .

31. Reardon D. A., Fink K. L., Mikkelsen T., Cloughesy T. F., O’Neill A., Plotkin S., Glantz M., Ravin P., Raizer J. J., Rich K. M., Schiff D., Shapiro W. R., Burdette-Radoux S., Dropcho E. J., Wittemer S. M., Nippgen J., Picard M., Nabors L. B. (2008) Randomized phase II study of cilengitide, an integrin-targeting arginine-glycine-aspartic acid peptide, in recurrent glioblastoma multiforme. $J$. Clin. Oncol., 26, 5610-5617.

32. Scherer R., Godoy H. T. (2009) Antioxidant activity index (AAI) by the 2,2-diphenyl-1picrylhydrazyl method. Food Chem., 112, 654-658.

33. Halliwell B., Gutteridge J. M. C., Aruoma O. I. (1987) The deoxyribose method: a simple test tube assay for determination of rate constants for hydroxyl radicals. Anal Biochem., 165, 215-219.

34. Marcocci L., Maguire J. J., M. T. Droy-Lefaix M. T. (1994) The nitric oxide-scavenging properties of Ginkgo biloba extract EGb 761. Biochem. Biophys. Res. Commun., 15, 748-755.

35. Suter M.; Richter C. (2000) Anti- and pro-oxidative properties of PADMA 28, a Tibetan herbal formulation'. Redox Report. 5, 17-22.

36. Auerbach R., Kubai L., Knighton D., Folkman J. (1974) A Simple Procedure for the Long-Term Cultivation of Chicken Embryos. Dev. Biol., 41, 391-394. 